\section{The Cult of Emptiness: The Western Discovery of Buddhist Thought and the Invention of Oriental Philosophy, by Urs App}

Kyoto: UniversityMedia, 20 I 2 | 304 pages | ISBN: 978-3-90600009-I (hardcover) \$40.76; ISBN: 978-3-906000-I 2-I (softcover) $\$ 27.90$

Urs App's The Cult of Emptiness is precisely what a scholarly book should be. It is faultlessly researched, clearly argued, engagingly written, and intellectually challenging. It is also what we might wish more books — of any kind — would be, in that it is often laugh-out-loud funny, deeply in tune with the glorious perversity of human history. The story it tells is at turns genuinely appalling and utterly delightful. In narrating the earliest European encounters with Buddhism and Buddhist philosophy, App holds up a brutally unflattering mirror to commonly held ideas about the world we live in (and how it come to be this way) and shows just how flawed those ideas really are.

He has a fine narrative sense, a keen eye for the telling detail, and a wickedly dark appreciation for the absurdity of it all. At times, the whole story of the initial contact between the West, in the form of Jesuit missionaries, and Japanese Buddhism, represented by a scattering of monks, politicians, writers, and a fugitive murderer, comes across rather like a series of pratfalls, mistaken identities, and wilful misunderstandings, a bit like a Shakespearean comedy but less eloquent and with far greater historical importance, more like a tragically consequential episode of Three's Company. Buddhist monks turn Buddhist philosophy into Christian theology. Christian missionaries turn Christian theology into what they thought was Buddhist philosophy and equate what they saw as the essence of Buddhism with tales from the Hebrew Bible. Even if some of this misunderstanding was wildly creative, a great deal of detail, nuance, and sense was simply lost in translation, and App argues convincingly that we are still struggling to get it all back, even hundreds of years later.

At the same time that it casts a wry, often amused glance at a complicated historical milieu, this is a serious and deeply reflective book. App grapples with fundamental questions of methodology and the place of scholarship within the larger culture, but interweaves this discussion so deftly with the 
rest of his analysis that it is never a self-important navel-gazing distraction, a common failing of too many academic books in the twenty-first century. App begins by arguing that the subject has not been given the proper scholarly attention:

Whereas the discovery by Europeans of the continents of our earth has been the subject of countless studies and its protagonists (such as Columbus) are universally known, research on the European discovery of our globe's "spiritual continents"-its religions and philosophies-is still in its infancy. The Christian West's discovery of Asia's largest religion and fount of philosophies, Buddhism, is a case in point: though it triggered one of the most significant spiritual and cultural encounters in world history, even the most basic questions remain unanswered. (I)

These questions, he notes, are fundamental given that the European invention of an imagined "Oriental religion" played "a crucial role in the premodern European perception of Asia and the genesis of modern orientalism" (3). These are matters, then, of some consequence, not mere historical footnotes. This act of perhaps unwitting invention saw the erasure of nuance and complexity; what emerged instead was the reductive notion of a single "Oriental philosophy," which, while not entirely fanciful, robbed Buddhism-to say nothing of Taoism, Jainism, Confucianism, and other Asian traditionsof much of its depth, its profundity, its difficulty, and ultimately its humanity. It also served to foreground a single aspect-the concept of $m u$, usually translated as "emptiness" - of a single form of Buddhism-monastic, aristocratic Japanese Zen-at the expense of all of the myriad other forms the tradition has taken in its long history.

The first chapter, aptly titled "Translation Hazards," takes the reader back to I 55 I's publication of the first Chinese-character document published in Europe, which detailed the donation by a group of monks of a Buddhist temple to Jesuit missionaries. There were mistakes from the earliest moments of contact. Both sides went looking for ways to make sense of new and unfamiliar ideas, falling back on the old and the familiar: "It is entirely fitting that the story of the Western discovery of Buddhism and the invention of a single 'Oriental philosophy' should begin with a fiasco involving the Arlecchino mechanism: Arlecchino is a main character of the Italian commedia 
dell'arte who thinks that the whole world is exactly like his family and acts accordingly" (I I).

This earliest textual encounter between Buddhism and the west shows the power of this Arlecchino mechanism on the Japanese side as "the Jesuits appear as representatives of Buddhism who inherit a Buddhist temple in order to promote the Buddhist religion" (I6). In turn, the Europeans, who first translated (to use the term generously) this document, hardly fared better, removing references to Buddhism in favour of vague terms such as "the law that produces Saints" (I6). As later chapters reveal, this sort of thing plays havoc with the documentary record, given that many important sources exist only in translations into Portuguese, Spanish, Latin, and Italian: "All we have at our disposal are reports showing how the missionaries understood what was said" (23).

The small Jesuit mission in the 1550 in Japan was beset by difficulties with Buddhist terminology and philosophy- "Some Zen adepts denied just about everything the Jesuits happened to affirm while others claimed that the Jesuits' teaching of Deos is identical with their doctrine" (33) — which led the missionaries to search for clarity in their ceaseless drive to win converts and spread Christian doctrine to a new and largely unknown land. Already by I 556, these missionaries were treating Buddhism as a "religion," and one distinct from Shinto, a separation that has a long and ideologically charged history both inside and outside of Japan. Crucially for App's central argument, these earliest missionaries wrote also of another separation, between the "outer" doctrines of Buddhism, including the existence of various deities as well as the Pure Land and various darker versions of an afterlife, which they argued that the monks taught to the laity (but did not themselves believe) and a purer "interior core of their law" that comprised the authentic heart of Buddhist doctrine (36).

This doctrine was profoundly atheistic and denied the existence of a soul or any form of an afterlife. It is this imagined inner essence that was to take root in European consciousness in the intervening centuries. This doctrine, profoundly this-worldly as it is, was compared by the missionaries to "the poison of the old serpent" from Genesis. The idea of emptiness that comprised the "inner" doctrine of Buddhism was thus understood in the light of what the Jesuits already understood about their own religion: "Arlecchino thus once more plays his trick: the Jesuits interpreted the unfamiliar philosophy in terms of what they were familiar with" (43). Again, App finds the mechanism at work in complex ways: "The Arlecchino effect was obviously 
at work not only for the Jesuits but also for the Japanese: each group detected in the other what it was already familiar with" (5I). The missionaries leaned on Greek and Latin philosophers and even more heavily on Aquinas and orthodox Christian theology, filtering their entire picture of Buddhism and Buddhist thought through these lenses:

Shaka's [the Buddha's] ultimate teaching thus fits the pattern that students of scholastic philosophy had learned to identify as typical of ancient Greek and Roman atheism: the denial of an omnipotent and omniscient creator God in favor of an eternal chaos or materia prima from which all beings, like waves in water, arise by chance only to eventually dissolve again into chaos in an endless cycle of birth and death. (45-46)

With a painstaking analysis of a vast, multi-lingual documentary record, App demonstrates convincingly that, although these earliest Christian writings about Buddhism were read almost solely by other missionaries, they nonetheless had a profound and lasting influence because such writings informed later works on Buddhism published widely in Europe. As the centuries passed, the local-Japanese Zen-became universal, while obscure missionary documents intended for other missionaries became the vehicle for widely accepted conceptions of an imagined East just beginning to permeate European consciousness at the very dawn of the modern age.

The second half of the book moves into the seventeenth century, as the earliest encounters between European missionaries and Buddhists in Japan continued to influence a growing, popular fascination with Buddhism and Buddhist thought in Europe. Portuguese Jesuits began an attempt to fit Buddhism and other Asian traditions into biblical understandings of history, still dominant in early-modern European thought. One influential writer concluded, in the I620s, for example, that the Chinese "seem to be descendents of Ham, because he held similar errors and taught them to his descendents, who then took them with them when they set off to populate the world" (IOI). Later commentators would then link Ham with Zoroaster, thereby bringing another set of religious traditions into the historical world of the Bible, regardless of the vast differences between the disparate traditions so casually thrown together. Still later writers would link all of the religious "errors" of Asia to an imagined "cult of the ancient Egyptians" (I24). The Buddha was thus assimilated not only to Jupiter, but also to Osiris. Thus, 
App argues, these writers painted a picture of "Asian religions and philosophies of branches of a single root-heresy" and "posited a fundamental unity of doctrine not only embracing much of Asia, but also the Greek and Roman world" (I27). The Buddha's "inner doctrine" also later became a way of attacking more native European movements, such as Spinozism: "The association of worrisome European movements with China's most detestable doctrine ... was an elegant and effective way of attacking such movements" (I78).

Throughout, App's linguistic skills and breadth are astonishing, even for a writer who has lived and worked in Asia for much of his career. He deals with original reports from missionaries written in Portuguese, Spanish, Italian, and Latin. He also translates or re-translates primary source materials in Japanese and Chinese. Throughout The Cult of Emptiness, App traces these complex chains of influence with a series of helpful flowcharts that help to make sense of the flood of names and terms that may be daunting to any reader less well versed than the author, which, I have to imagine, would be most of them. Drawing often on materials from his own personal library, from which he also takes much of the most telling textual evidence, he also presents an intriguing and at times very amusing pictorial history of these ideas and the way they travelled through time and over vast distances. As the book draws to a close, App demonstrates the vast and varied influence of these ideas in later centuries:

Once it had taken root and begun to bloom on European soil, the beguiling perfume of the flower of the imagination called "Oriental philosophy" was to waft through the entire eighteenth century, persistent like musk and clinging like patchouli. It enthralled church historians like Mosheim, historians of philosophy like Brucker, encyclopaedists like Diderot, and even famous orientalists like Jospesh de Guignes and Anquetil-Duperron. Hegel's lecture on Asia of the I 820 , French debates about Buddhism's "cult of nothingness" in the I 850 , and countless discussions of the meaning of "nirvana" in the nineteenth and twentieth centuries still exuded its unmistakable, intoxicating scent. (237)

The Cult of Emptiness serves as a case study for just how deeply Christian texts, ideas, and systems of categorisation are ingrained in the history of 
the Western world, and just how far-in terms of both distance and timescholars and historians have to go to uncover this influence. We will perhaps never free ourselves from such influences, as they are the warp and weft of our picture of history, but App shows us that it is worth the effort. At the same time as he uncovers these hidden chains of influence, reading, and re-reading, App hammers home his central —if unstated — thesis: bad ideas have wings. They travel. They persist. They even thrive. But that doesn't mean we have to like them.

On an entirely different matter, this review is to be my last as sometime co-editor and co-founder of Relegere, as academia and I have largely parted ways, and not entirely amicably. My thanks to our readers, our contributors, and especially to James, Deane, and Will for the opportunity to be a part of a rigorously independent venture and the chance to do some work I can be truly proud of (now that I am an ordinary citizen again, I re-claim the right to end sentences with a preposition). I wish them-and you, Constant Reader-the best of luck in the future.

Eric Repphun

Independent 